\title{
Effectiveness of An Educational program on Critical Care Nurses`Performance and Patients Outcomes Regarding Physical Restraint
}

\author{
Amal Fawzy Zaki ${ }^{1}$, Amal Said Taha ${ }^{2}$ and Samah El Sayed Ghonaem ${ }^{3}$ \\ (1) Clinical Instructor at Technical Institute of Nursing in Zagazig University, (2) Assistant Professor of \\ Medical Surgical Nursing- Faculty of Nursing-Benha university and (3) Assistant Professor of Medical \\ Surgical Nursing- Faculty of Nursing-Benha University
}

\begin{abstract}
Back ground: Physical restraint is used to prevent therapy discontinuation, patients` falls and injuries, and to protect patients from removing tubes, drains, and medical equipment connected to their body. Aim of the study: To evaluate the effectiveness of an educational program on critical care nurses ' performance and patients outcomes regarding physical restraints. Research design: A quasi experimental research design was utilized to conduct this study. Sample: A convenient sample consisted of 60 critical care nursing staff working in intensive care unit who apply physical restraint to critical ill patients and A purposive sample includes 72 patients were admitted to intensive care unit up to six month. Tools of data collection: Data were obtained through two tools; Self-administered questionnaire for nurses, Nurses' practice observational checklist tool and clinical outcomes tool for patients. Results: There was highly statistically significant differences in the total mean knowledge and practice scores of studied nurses immediately post and after one month of program implementation as compared to preprogram implementation. Also, there was statistically significant correlation between nurses` total knowledge and patient outcome with statistically significant between nurses` total practice and patient outcomes immediately post and after one month. Conclusion: There was a highly statistical significant improvement of studied nurses` knowledge and practice through program phases, which indicated that improved patients' outcome. Recommendations: Orientation programs are needed for newly graduated nurses to improve their practice and knowledge and to maintain effective nursing care for patient under physical restraint.
\end{abstract}

Keywords: Educational Program, Nurses`Performance, Patients`outcome and Physical restraint.

\section{Introduction}

Physical restraint is the action or procedure restricting a person's freedom of movement, physical activity, or normal access to his/her body by the use of any physical or mechanical tools and devices attached to the patient's body It is commonly used in hospitals especially in the intensive care unit settings when patients' are confused, physically harmful to themselves and others, and when the alternative methods are inadequate or contraindicated (Abraham et al., 2020).

Around $80 \%$ of critically ill patients who are admitted to the intensive care unit(ICU) may require to be physically restrained due to the presence of agitation, confusion, sleeplessness, and disruptive behaviors these behaviors causes removal of life support medical devices, falling injure, and danger to patient him/herself or others. 


\section{Outcomes Regarding Physical Restraint}

ICU staffs try to reduce those behaviors by using different measures like settling the attendant with patients, lowering bed height, raising bed rails, and using the sedating medication before physical restraint (Zulian et al., 2020).

Complications of physical restraint application among critical ill patients may develop pressure sore, limb edema, restricted circulation, and skin laceration at restraint site. These complications can be prevented by the closely monitoring and change of care plan by nurses; the nursing care plan should be containing regular changes of patient position, skin care and a sufficient range of motion. The assessment of the patient's response hourly, removing the restraints every two hours, frequent change of patients` position, in addition to assessing the patient for any physical and psychological effects of restraining (El-sol \& Mohmmed 2018).

\section{Significance of the study}

In Egypt, physical restraint is a more conventional practice in ICUs (Younis \& Ahmed, 2017). Physical restraints are considered an acceptable practice in many settings .In a study in the United States, the intensive care units (ICUs) accounted for $56 \%$ of all restraint days despite having only $16 \%$ of all the patient-days. Physical restraints are a common practice in healthcare, with prevalence rates ranging between $15 \%$ and $66 \%$ in nursing homes and between $33 \%$ and $68 \%$ in hospital settings. Several works of literature reported that the prevalence of physical restraint use among critically ill patients ranged from $62 \%$ to $79 \%$ worldwide (Kassew ,Tilahun \& Liyew, 2020).

\section{Aim of the study:}

The aim of this study was to evaluate the effectiveness of an educational program on critical care nurses` performance and patients' outcomes regarding physical restraints.

\section{Research Hypothesis}

-The mean knowledge scores of nurses who are exposed to educational program of physical restraint will be higher than before

- The mean practice scores of nurses who are exposed to educational program of physical restraints will be higher than before..

- The frequency of physical complications among studied patients will be lower than before.

- There will be a positive relation between nurses` knowledge, practice and then with patients outcomes.

\section{Subjects and method}

\section{Research design:}

A quasi experimental research design was utilized to meet the aim of this study.

\section{Setting:}

The study was conducted at Intensive Care Unit in Benha University Hospital

\section{Subjects}

For nurses: A convenient sample was used in this study composed of 60 nurses working in previously mentioned setting, was recruited to this study.

For patients: A purposive sample composed of 72 patients was used in this study admitted at the above mentioned setting up to six month.

Sample included in the study were selected according to the following criteria:

\section{Inclusion criteria:}

Both sexes and patient aged between to 60 years old.

-Patient must be at high risk for falling

-Irritable patients

-Disturbed consciousness level

-Mechanically ventilated patient to prevent remove lifesaving tubes or devices 
Tools for data collection:

\section{Tools for nurses:}

The data was collected through the following tools:

\section{Tool I: Structured interviewing questionnaire}

for nurses: This tool was developed by the researcher. It was include two parts as the following:

Part I: Socio demographic data: It was concerned with socio-demographic characteristics of nurses. It included 8 close ended questions about name, sex, age, marital status, level of education, year of experience in nursing profession, year of experience in intensive care unit, and training courses about physical restraint.

Part II: Nurses` knowledge (pre/ post test): It was concerned with the assessment of nurses' knowledge regarding physical restraint. It consists of 21 multiple choice questions. It included 3 items and disturbed as the following: specific questions for nurses regarding physical restraint which was included (6 questions), knowledge about complication \& factors that affect the optimal application of physical restraint, which was included 10 questions, and knowledge about nursing care for patients under physical restraint which was included 5 questions

\section{Scoring system:}

Score $\geq \mathbf{7 5 \%}$ was considered adequate level of knowledge.

Score $<\mathbf{7 5 \%}$ was considered in adequate level of knowledge

Part III: Nurses` practice assessment (pre/ posttest): This tool developed by the researcher after reviewing related literature to assess the nurses' practice regard physical restraint. The observational checklist divided into 3 parts.

Part I wrist restraint observational check list composed of 41 steps

Part II belt restraint observational check list composed of 43 steps
Part III leg restraint observational check list composed of 41 steps

\section{Scoring system:}

The scoring system of practice for each step was calculated as follows:

1 score $=$ Done

Zero $=$ Not done

Tools for patients:

Tool II: Structured interviewing questionnaire for patients:

It was developed by the researcher based on literature review. It was included four parts as the following:

Part I: Patient's socio demographic characteristics: It included (Age, gender, occupation, level of education, and marital status)

Part II: Patient's clinical data: It included 7 questions as medical diagnosis, presence of chronic disease, causes of physical restraint, duration of physical restraint, The type of material used in the patient's physical restraint, location of restraint and duration of stay in intensive care unit.

Part III: patient physical assessment This tool was adopted from (Abu Awwad,2014) which consists of neurovascular check for restrained part, vital signs, behavioral assessment and hygiene for restrained parts.

Part VI: Complication assessment. This tool was adopted from (Hafez, 2011), and used to evaluate and monitor patients for the development of complications before and after implementing the educational nursing program. types of complications that result from physical restraint application. It consists of four types: direct, indirect, potential and psychological complication

\section{- Preparatory phase:}

It was include reviewing of past and current related national, international literature and theoretical knowledge of various aspects of the study using books, articles, and exploring 
internet's and periodicals and magazines to develop tools for data collection.

\section{Content validity:}

Validity of tools was done by a group of experts to check the relevancy, clarity, comprehensiveness, and applicability of the questions. According to their opinion, minor modifications were done and the final forms were developed. Face and content validation of the studied tools were done according to opinions of the 7 experts in related fields.

\section{Reliability:}

Reliability of the developed tools was done statistically through Chronbach`s Alpha test to measure the internal consistency of the tool. that was 0.83 for nurse`s knowledge questionnaire and 0.63 for nurse`s practice observational check list and 0.54 for direct complication and 0.75 for indirect complication.

\section{Ethical considerations:}

Written approval was obtained from the research ethical committee of faculty of nursing, also an official permission was obtained from hospital administrators to conduct the study. Each nurse and patient was informed about the purpose, nature and significance of the study,

\section{Pilot study:}

A pilot study was carried out on $10 \%$ of the study subjects (6 nurses and 7patients) in order to test the clarity, applicability, feasibility, relevance of the data collection, and to identify any possible obstacles that may hinder the data collection. Nurses and patients involved in the pilot study were included in the total study subjects as no modifications were done.

\section{Field work:}

The study was conducted over period of 6 months started from June 2020 to the end of November 2020. Data was collected 4 days (Saturday, Sunday, Monday, and Thursday) per week at morning and afternoon shifts in intensive care unit at Benha University.

The field work was included four phases:
Phase I: "Assessment phase":

After the study program has been approved, an official permission was taken from the director of Benha university hospital after explanation of the purpose of the study. Once the researcher has gained the approval; the researcher visited the setting and met nurses and patients to explain the purpose and nature of the study in order to gain their cooperation before data collection. During this phase, the researcher met nurses after introducing herself; a full explanation of the study aim was done to obtain their approval and cooperation as well as their verbal consent.

Phase II: "Planning phase": Educational Program was designed in Arabic language by the researcher based on nurses' need after reviewing the most recent literature and provided in a form of a booklet. Booklet was color printed and was supplemented by photos for more illustration and to help the nurses to understand the content. The nurses` learning needs were identified and classified into knowledge and practice. Detected needs, requirement and practice deficiencies were translated to aim and objectives of educational program.

\section{Phase III" Implementation phase"}

- During this phase the nurses were divided into small groups (3-4 nurses). Each group received the same program content by using the same teaching strategies and the program was provided on small sessions (2030 minutes) the number of sessions was varied according to their level of understanding

Phase IV "Evaluation phase":

- Studied nurses were interviewed immediately after implementing the educational program (post-test evaluation) and data collection was done by using (tool I). 
- $\quad$ Practice of nurses was observed and checked by researcher to fill out tool I (Part III)

\section{Results:}

Table(1) reveals that more than three quarter $(78.3 \%)$ of the studied nurses 'ages were between the 20 to less than 30 years old with Mean $\pm \mathrm{SD}=28.89 \pm 5.02$, and more than two thirds of them $(70.0 \%)$ were female and married. Besides, one half of them $(50 \%)$ were graduated from the technical institute of nursing. While, slightly less than two thirds of them $(60.0 \%)$ had 1 to less than 5 years of experience in nursing shows that $34.7 \%$ of the studied patients had ischemic stroke , $27.8 \%$ of them had COPD and $20.8 \%$ had trauma while $16.7 \%$ of them had pre hepatic coma. As regards to history of chronic $32.7 \%$ had diabetes. Concerning to reasons that led to restriction of the patient $59.7 \%$ of studied patient restrained due to removal medical device linked to them.

Table (4): describes that, there was statistically significant correlation with negative correlation between the studied nurses` total knowledge and patient outcome at immediately post program. Additionally, there was statistical significant correlation between studied nurses` total knowledge and patient outcome after one month of program implementation. This indicated that improvement in nurses` knowledge, and patient profession and ICU with Mean $\pm \mathrm{SD}=4.80 \pm 3.22$. Lastly, most of the studied nurses $(96.7 \%)$ had not attended previous training courses regarding physical restraint.

Table (2): shows that $41.6 \%$ of the studied patients were in age group of more than 50 years and $59.7 \%$ of them were male but $76.3 \%$ were married. As regards to patient's education $63.9 \%$ of them had secondary .As regards to occupation $41.7 \%$ of the studied patients were work.

\section{Table (3):}

diseases $68.1 \%$ of studied sample had chronic diseases. Regarding to type of chronic diseases, it was found $40.8 \%$ of studied sample had hypertension followed outcome in immediately post of program implementation

Table (5): describes that, there was statistically significant correlation with negative correlation between the studied nurses` total practice and patient outcome at immediately post program and after one month $(\mathrm{p} \leq 0.05, \mathrm{r}=0.253$ respectively $\mathrm{P}<0.013, \mathrm{r}=0.320$ ).This indicated that improvement in nurses practice, patient outcome in immediately post and after one month of program implementation. 
Effectiveness of An Educational program on Critical Care Nurses` Performance and Patients Outcomes Regarding Physical Restraint

Table (1): Frequency and percentage distribution of studied nurses regarding their Demographic Characteristics $(n=60)$

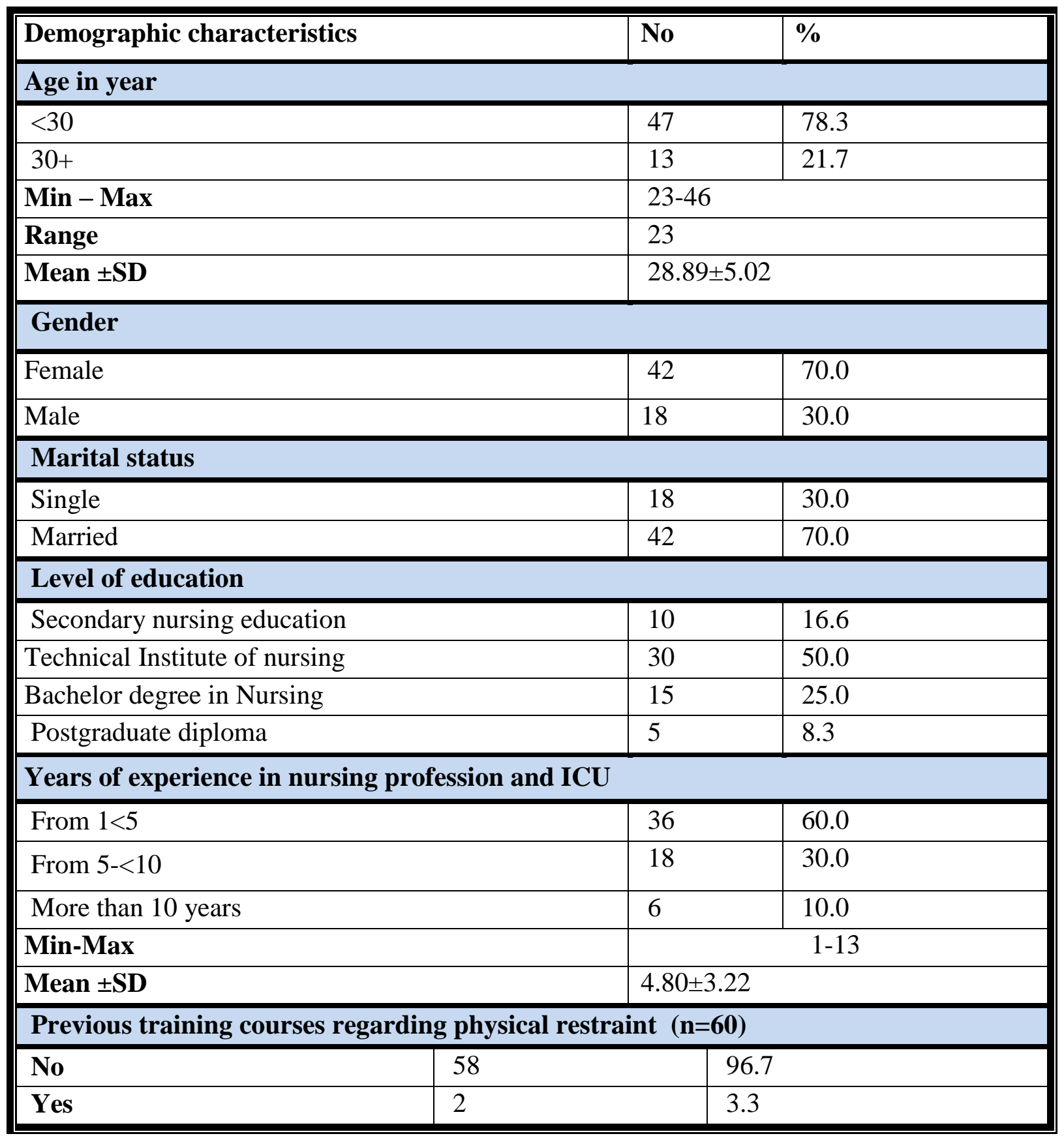


$\underline{\text { Amal Fawzy Zaki, Amal Said Taha and Samah El Sayed Ghonaem }}$

Table 2: Frequency and percentage distribution of studied patient regarding their demographic characteristics $(n=72)$.

\begin{tabular}{|c|c|c|}
\hline Demographic characteristics & No & $\%$ \\
\hline \multicolumn{3}{|l|}{ Age in years } \\
\hline$<30$ & 8 & 11.1 \\
\hline $30-<40$ & 14 & 19.4 \\
\hline $40-<50$ & 20 & 27.8 \\
\hline $50+$ & 30 & 41.6 \\
\hline Min-Max & \multicolumn{2}{|l|}{$26-66$} \\
\hline Range & \multicolumn{2}{|l|}{40} \\
\hline Mean \pm SD & \multicolumn{2}{|l|}{$=50.06 \pm 12.084$} \\
\hline \multicolumn{3}{|l|}{ Gender } \\
\hline Male & 43 & 59.7 \\
\hline Female & 29 & 40.3 \\
\hline \multicolumn{3}{|l|}{ Marital status } \\
\hline Single & 7 & 9.7 \\
\hline Married & 55 & 76.3 \\
\hline Widowed & 10 & 13.8 \\
\hline \multicolumn{3}{|l|}{ Educational level } \\
\hline Can`t Read \& Write & 5 & 6.9 \\
\hline Basic education & 4 & 5.6 \\
\hline Secondary & 46 & 63.9 \\
\hline University & 17 & 23.6 \\
\hline \multicolumn{3}{|l|}{ Occupation } \\
\hline Working & 30 & 41.7 \\
\hline Not working & 25 & 34.7 \\
\hline Retired & 17 & 23.6 \\
\hline
\end{tabular}


Effectiveness of An Educational program on Critical Care Nurses` Performance and Patients Outcomes Regarding Physical Restraint

Table (3): Frequency and percentage distribution of studied patient regarding their diagnosis, medical history and Reasons for use physical restraint $(n=72)$.

\begin{tabular}{|l|l|l||}
\hline Clinical Data & No & \% \\
\hline Diagnosis & 20 & 27.8 \\
\hline Chronic obstructive pulmonary diseases & 12 & 16.7 \\
\hline Pre hepatic coma & 25 & 34.7 \\
\hline Acute Ischemic Stroke & 15 & 20.8 \\
\hline Trauma & \multicolumn{2}{|l|}{} \\
\hline Presence of chronic disease & 23 & 31.9 \\
\hline No & 49 & 68.1 \\
\hline Yes & 16 & 32.7 \\
\hline If yes (n=49). & 20 & 40.8 \\
\hline Diabetes & 5 & 10.2 \\
\hline Hypertension & 8 & 16.3 \\
\hline Renal disease & 15 & 20.8 \\
\hline Hepatic disease & 4 & 5.6 \\
\hline Reasons that led to restrict the patient & 10 & 13.9 \\
\hline Confusion and lack of awareness of situations & 15 & 59.7 \\
\hline Self-harm & 43 & \\
\hline Harming other and those around & Removal of medical device linked to him & \\
\hline
\end{tabular}

Table (4): Correlation between total nurse`s knowledge and patient outcome through the program phases (pre, immediately post, after one month of program) $n=72$

\begin{tabular}{|l|l|l|l|l|l|l|}
\hline \multirow{3}{*}{ Variable } & \multicolumn{2}{|l|}{ Total nurse`s knowledge } \\
\cline { 2 - 7 } & \multicolumn{2}{|l|}{ Preprogram } & \multicolumn{2}{l|}{$\begin{array}{l}\text { Post } \\
\text { Immediately }\end{array}$} & \multicolumn{2}{l|}{ After one month } \\
\cline { 2 - 7 } & R & $\begin{array}{l}\text { P- } \\
\text { value }\end{array}$ & R & P-value & R & P-value \\
\hline patient outcome & -0.148 & .259 & -0.587 & $.041^{*}$ & -0.471 & .046 \\
\hline
\end{tabular}

*A statistical significant difference $(p \leq 0.05) * * A$ highly statistically significant differences $(\mathbf{p} \leq \mathbf{0 . 0 0 1 )}$ 
Table (5): Correlation between total nurses' practice and patient outcome through the program phases (pre, immediately post, after one month of program $(n=72)$

\begin{tabular}{||l|l|l|l|l|l|l||}
\hline \multirow{3}{*}{ Variable } & \multicolumn{4}{|l|}{ Total nurses practice } & \multicolumn{4}{l||}{ Post Immediately } & \multicolumn{2}{l|}{ After one month } \\
\cline { 2 - 7 } & Preprogram & $\begin{array}{l}\text { P- } \\
\text { value }\end{array}$ & R & P-value & R & P-value \\
\cline { 2 - 7 } patient outcome & .132 & .315 & -.253 & $.05^{*}$ & -.320 & $.13^{*}$ \\
\hline
\end{tabular}

$*$ A statistical significant difference $(p \leq 0.05) * * A$ highly statistically significant differences $(p \leq 0.001)$

\section{Discussion:}

Regarding age, The finding of the present study revealed that, more three quarters of studied nurses were between the age 20 to less than 30 years old. This may be related to most of nurses were newly graduated. This result was consistence with the result of Salehi et al., (2020) whose study was about "Factors behind ethical dilemmas regarding physical restraint for critical care nurses, master thesis, Iran University of Medical Sciences \& Iran, and stated that the majority of their studied nurses were in age ranged between 20 and 30 years old

As regards to gender, the results of present study showed that, more than two thirds of studied nurses was female. From the present study researcher's point of view this may be due to this reaffirms the notion that nursing is still predominantly female dominated profession. Similarly Kaya \& Dogu, (2018) whose study was about "Intensive Care Unit Nurses' Knowledge, Attitudes And Practices Related To Using Physical Restraints, master thesis,
Istanbul University\& Turkey, who was found in their study that more than two thirds $(79.4 \%)$ of the intensive care nurses participated to the study were female

Concerning marital status, the results of present study revealed that, more than two thirds of studied nurses were married. This result was congruent with Almomani et al.,(2021) whose study was about 'Nurses' knowledge and practices of physical restraints in intensive care units at Faculty of Nursing, Jordan University of Science and Technology" found in their study that more than two third of the studied nurses were married.

In respect to the level of education: of the studied nurses in present study showed that one half of studied nurses were graduated from the technical institute of nursing. This may be due to the fact that technical institutes of nursing provide the health care agencies with large numbers of graduated nurses than nursing faculties as they graduated after 2 years of education .This finding was consistent with Abd Elhameed \& Elemam (2020) whose study was about" Nurses Knowledge, Intention and 


\section{Patients Outcomes Regarding Physical Restraint}

Attitude towards the Use of Physical Restraint in Geriatric Care, master thesis, Mansoura University\& Egypt" who mentioned that half of their studied nurses were graduated from technical institute of nursing

As regards years of experience, around slightly less than two thirds of the studied nurses reported having less than five years of experience in nursing profession and in intensive care unit this may be rationalized as the fact that most of the studied nurses were newly graduated. This finding was consistent with the present study Karaca et al., (2018) who study was about "Physical restraint use in elderly patients: perceptions of nurses in university hospitals. "who was found in their study that less than half of studied nurses had less than five years of experience

As regards training courses regarding physical restraint: The results of this study illustrated that most of the studied nurses had not attended previous training courses regarding physical restraint. This may be due to the hospital do not provide any training course, there is no special policy that regulates the application of physical restraint and nurses said that there is not enough time to attend such courses .This finding was consistent with the present study Via-Clavero et al.,(2020).whose study was about "Factors influencing critical care nurses' intentions to use physical restraints adopting the theory of planned behavior" who reported that most of their studied nurses not attended previous training courses regarding physical restraint

Regarding to nurse's knowledge about physical restraint as regards to definition of physical restraints, slightly less than half of studied nurses unable to define physical restraint before implementation of program. This may be due to lack of training courses about physical restraint. This supported by Ahmed, Mohamed \& Abdelhalim, (2018) who study was about
"Factors Affecting Nurses' Performance Regarding Use of Physical Restraints in Critical Care Unit, master thesis, ,Ain Shams University\& Egypt" who mentioned that more than one half of studied nurses unable to define physical restraint

Regarding to mean and stander deviation of total nurses' practices (wrist, belt, and leg restrain) through the program phases. mean score of nurses' total practice regarding physical restraint in pre and immediately post program implementation were $25.96 \pm 4.53$ and $118.23 \pm 3.36$ respectively and $115.40 \pm 8.97$ after one month of program implementation. Also, in this table there was a highly statistically significant difference $(\mathrm{p}<0.000)$ in mean of all total practice scores among pre, immediately post and after one month of program implementation. These findings came in consistence with Eskandaria et al., (2018) who found that the nurse's mean score of nurses' total knowledge were $10.89 \pm 3.59$ and $115.34 \pm 4.98$ respectively and $110.30 \pm 6.97$ and concluded that educational intervention resulted in a statistically significant increase in the mean practice

By studying the correlation between total knowledge score and total practices score of studied nurses the present study revealed that there was positive relation between total knowledge score and total practice score. This means that knowledge and practice are interrelated as when knowledge increase a practice of physical restraint will also be improved. Similar finding was reported by Pradhan et al., (2019) who reported that there was a significant positive correlation between nurses' practice score and that of knowledge.

\section{Patient outcome:}

Regarding age: The finding of the present study revealed that, slightly less than one half (41.6\%) of studied patient's age more than 50 years old. This may be due to advanced age is one of the main factors causing patients' agitation and 
consequently putting them into the risk of pulling the life support devices and catheters or harming themselves and others This result was consistent with the result of Kalula, \& Petros, (2016). Who study was about "Use of physical restraint in hospital patients: A descriptive study in a tertiary hospital in South Africa" and stated that half of their patients age was 50 years old and more

Regarding gender and marital status: The current of present study revealed that more than half of studied patients were male are more likely to be physically restrained. This may be due to male patients are more prone to restlessness and discomfort with treatment and more than three quarter of them were married This result agreed with Suliman, (2018) who study was about "Prevalence of physical restraint among ventilated intensive care unit patients" who reported that more than half $(57.9 \%)$ of their patients studied were male and majority of them were married.

As regards to level of education: the current study revealed that slightly less than two thirds of studied patient graduated from secondary school (diplom). This result disagreed with Chou et al., (2020) who study was about "The Adverse Effects of Physical Restraint Use among Older Adult Patients Admitted to the Internal Medicine Wards" reported that most of their patients graduated from primary school

\section{Regarding to occupation for patients the} present study revealed that, slightly less than half of studied patients were working. This result agreed with Doma \& Abo El-yzeed, (2016) who study was about "Patients and Nurses' Opinion about uses of physical restraint for psychiatric patients in Mental Health Hospital. Tanta University" who reported that half of their studied patients (50.0\%) were worked.
For medical diagnosis of studied patients the finding of present study revealed that, about one third of studied patients had acute ischemic stroke. From the investigator's point of view, this may be due to these patient were inability to control anger and aggression so, these patient need restraint for protection and safety. This finding agreed with Kisacik \& Cosgun,(2019) who conducted a study to "evaluation of physical restraint practices and their neurovascular effect on intensive care unit patients $\mathrm{PhD}$, Turkey", mentioned that slightly less than one third $(27.5 \%)$ of the their patients had ischemic stroke.

Regarding to the presence of chronic diseases, the results of this study revealed that more than two thirds of study sample had chronic diseases about more than one third of them had hypertension and slightly less than one third of them had diabetes This may be due to patients with chronic diseases are more liable to be restrained as well as they exposed for more complications. This supported by Ertugrul, B., \& Ozden, D. (2020) who study was about "The effect of physical restraint on neurovascular complications in intensive care units, $\mathrm{PhD}$, Nursing Faculty, Izmir, Turkey" reported that most of their patients had chronic diseases such as hypertension and diabetes.

Concerning to reasons that led to restrict patients in this study results revealed that more than half of studied sample were restricted due to removal of medical device linked to them and less than one quarter of the patients restricted due to confusion and lack of awareness of situations from the present study researcher's point of view, this may be due to, patients in ICU have many drainages tubes and are exposed to more sedative drugs which may make them delirious and not in control of their movements that lead to accidental removal of surgical drains In this respect Suliman, M. (2018) whose study was about "Prevalence of physical restraint among 


\section{Effectiveness of An Educational program on Critical Care Nurses`Performance and \\ Patients Outcomes Regarding Physical Restraint}

ventilated intensive care unit patients, $\mathrm{PhD}, \mathrm{Al}$ al-Bayt University, Jordan" reported that studied patients restricted due to removal of medical device linked to them, confusion and lack of awareness of situations.

In current study there were statistically significant difference with negative correlation between the studied nurses` total knowledge and practice and patient outcome at immediately post program. This indicated that improvement in nurses` knowledge and practice, and patient outcome in immediately post of program implementation. The findings were in congruence with Taha \& Ali, (2013). Who was found statistically significant differences with negative correlation between the studied nurses` total knowledge and practice and patient outcome at immediately post program

\section{Conclusion:}

The post means the mean knowledge scores of nurses who are exposed to educational program of physical restraint were higher than before. It revealed that, the low mean score preprogram implementation was concerning nurses knowledge about physical restraint and patient outcome. On other hand, the mean scores were increased immediately post and after one month of program implementation with a high statistical significant difference $(\mathrm{P} \leq 0.001)$ from preprogram implementation. Moreover, the post means practice scores of nurses were higher than their pre practice mean scores. It reflected that, the low mean score preprogram implementation was concerning nurses` practice about physical restraint and patient outcome, On other hand, the mean scores were increased immediately post and after one month of program implementation with a high statistical significant difference $(\mathrm{P} \leq 0.001)$ from preprogram implementation.

\section{Recommendation:}

- Nurses require ongoing education, training, and evaluation of training effectiveness to ensure that they are aware of the details of program regarding physical restraint, particularly when this program is modified and updated.

-Evaluate strategies to improve nurses' knowledge of physical restraint and clinical practice guidelines recommended for the maintenance of patient physical safety in intensive care unit

\section{References}

Abraham, J., Hirt, J., Kamm, F., \& Möhler, R. (2020). Interventions to reduce physical restraints in general hospital settings: A scoping review of components and characteristics. Journal of clinical nursing, 29(17-18), 3183-3200.

Abd Elhameed, S. H., \& Elemam, N. I(2020). Nurses Knowledge, Intention and Attitude towards the Use of Physical Restraint in Geriatric Care. Faculty of Nursing, Mansoura University. IOSR Journal of Nursing and Health Science, 9(1). 30-38

Abu Awwad MH (2014). Relationship between the Nursing Practice in the use of Physical Restraints and Critically Ill Patient Physiological Parameters. Faculty of Nursing. Alexandria University.

Almomani, M. H., Khater, W. A., Qasem, B. A. A. A. L., \& Joseph, R. A. (2021). Nurses' knowledge and practices of physical restraints in intensive care units: An observational study. Nursing Open, 8(1), 262-272.

Chou, M. Y., Hsu, Y. H., Wang, Y. C., Chu, C. S., Liao, M. C., Liang, C. K., ... \& Lin, Y. T. (2020). The Adverse Effects of Physical Restraint Use among Older Adult Patients Admitted to the Internal Medicine Wards: A Hospital-Based Retrospective Cohort Study. The journal of nutrition, health \& aging, 24(2), 160165.

Doma, H. H., \& Abo El-yzeed, S. M. (2016). Patients and Nurses' Opinion about uses of physical restraint for psychiatric patients in Mental Health Hospital. Tanta Scientific Nursing Journal, 11(2), 44-65.

El-sol, A. E. S. H., \& Mohmmed, R. G. A. (2018). Assessment of nurse's knowledge, attitudes, and practice regarding physical 
restraints among critical ill patients. Assessment, 4(1), 15-22.)

Ertuğrul, B., \& Özden, D. (2020. The effect of physical restraint on neurovascular complications in intensive care units. Australian Critical Care, 33(1), 30-38.

Hafez EM (2011). Problems encountered among patients Utilizing Physical Restraint in Mansoura university hospitals. Faculty of Nursing .Zagazig University.

Kassew, T., Dejen Tilahun, A., \& Liyew, B. (2020). Nurses` Knowledge, Attitude, and Influencing Factors regarding Physical Restraint Use in the Intensive Care Unit: A Multicenter Cross-Sectional Study. Critical Care Research andPractice, 2020.1-10.

Doi.org/10.1155/2020/4235683

Kalula, S. Z., \& Petros, S. G. (2016). Use of physical restraint in hospital patients: A descriptive study in a tertiary hospital in South Africa. Curationis, 39(1), 1-8.

Karaca, T., Aydin Ozkan, S. E. M. İ. H. A., \& Derya Ister, E. (2018). Physical restraint use in elderly patients: perceptions of nurses in university hospitals. Türk Geriatri Dergisi, 21(4), 588-595.

Kaya, H., \& Dogu, O. (2018). Intensive care unit nurses' knowledge, attitudes and practices related to using physical restraints. International Journal of Caring Sciences, 11(1), 61-70.

Kisacik, O. G., \& Cosgun, T. (2019). Evaluation of Physical Restraint Practices and Their Neurovascular Effect on Intensive Care Unit Patients. Dahili ve Cerrahi Bilimler Yogun Bakim Dergisi, 10(2), 53.

Salehi, Z., Najafi Ghezeljeh, T., Hajibabaee, F., \& Joolaee, S. (2020). Factors behind ethical dilemmas regarding physical restraint for critical care nurses. Nursing Ethics, 27(2), 598-608.

Suliman, M. (2018). Prevalence of physical restraint among ventilated intensive care unit patients. Journal of Clinical Nursing, 27(19-20), 3490-3496.

Taha, N. M., \& Ali, Z. H. (2013). Physical restraints in critical care units: impact of a training program on nurses' knowledge and practice and on patients' outcomes. J Nurs Care, 2(2), 1-9.

Via-Clavero, G., Guàrdia-Olmos, J., FalcóPegueroles, A., Gil-Castillejos, D., LoboCívico, A., De La Cueva-Ariza, L., ... \& Delgado-Hito, P. (2020). Factors influencing critical care nurses' intentions to use physical restraints adopting the theory of planned behaviour: A cross-sectional multicentre study. Australian Critical Care, 33(5), 426-435.

Younis, G. A., \& Sayed Ahmed, S. E. (2017). Physical Restraint and Maintenance of critically ill patient's safety in Intensive Care Unit: Effect of Clinical practice guidelines on nurse's practice and attitude. Nurs Health Sci, 6, 6-21.

Zulian, L. R., Mori, S., Teraoka, E. C., Miyasaki, V. Y. K., Zanei, S. S. V., \& Whitaker, I. Y. (2020). Factors associated with the use of physical restraint in intensive care patients. Revista da Escola de Enfermagem da USP, 54 (1). 7-31 
فاعلية برنامج تعليمي علي أداء تمريض الرعاية الحرجة ونتائج المرضي فيما يتعلق بالتقييد الجسماني أمل فوزي زكي ـ أمل سعيد طهـ سماح السيد غنيم

التقيد الجسماني هو وسيلة أو جهاز مجاور لجسم المريض الذي يقيد حركته ويستخدم التقييد الجسماني بشكل كبير في مرضي وحدة العناية المركزة. حوالي •^^\% من المرضي في وحدات العناية المركزة تعاني من تغير في مستوي درجة الوعي أثناء إقامتهم بسبب الألم ونقص الأكسجين وأعر اض الإنسحاب من المواد المخدرة و الكحوليات، قد يحاول هؤلاء المرضي إزالة الأجهزة ومتعلقات طبية مثل أجهزة التنفس الصناعي ، الأنبوبة المعدية ، قسطرة البول وغير ها لذلك يستخدم التقييد الجسماني لمنع حدوث أي مضاعفات. لذلك هدفت هذه الرسالة إلي تقييم تأثير برنامج تعليمي علي أداء تمريض الرعاية الحرجة ونتائج المرضي فيما يتعلق يالتقييد الجسماني. وتم تحديد ، 7 ممرض وممرضه بالعناية المركزة. وقد كثفت النتائج عن تطبيق البرنامج التعليمى له تأثير ايجابي على معلومات وأداء الممرضات عن كيفية تقديم العنايه التمريضيه للمرضي تحت التقييد الجسماني، كما أوصت الدر اسه أنه يجب توفير كتيب مبسط وشامل لجميع الممرضات بالعناية المركزة والذى يتضمن شرحاو اضحا ومختصر ا وبسيطا عن كيفية تقديم العنايه التمريضيه للمرضي تحت التقييد الجسماني. 